\title{
INHABITANT'S SENSE OF PLACE IN THE CONTEXT OF TOURISM KAMPUNG
}

\author{
Annisa Nur Ramadhani*, Muhammad Faqih*, Arina Hayati* \\ *) Architecture Department, Faculty of Architecture Design and Planning, Institut \\ Teknologi Sepuluh Nopember, Surabaya, Indonesia \\ e-mail: annisa.arch@gmail.com
}

\begin{abstract}
Kampung improvement program in Surabaya is considered successful in enhancing the quality of housing and settlement based on sustainable development. Recently, the kampungs development is directed toward tourism thematic (Thematic Tourism Kampung Programme) that adopts cultural conservation value. The goals are not only to improve the socio-economic prosperity of Kampung's people, but also to conserve the kampung's culture and tradition. As a consequence, the function and meaning of kampung may change from urban kampung to tourism kampung. The kampung settlement becomes more accessible to the public visitors and affect the kampung's sense of place to its inhabitants. This paper aims to enrich the model of sense of place in the context of tourism kampung development in Surabaya. This study is developed through literature review of relevant studies and in-depth interview with some respondents. The different theories of sense of place are reviewed to show the need of a shared definition of what constitutes a sense of place, its features, and its performance in the specific context (tourism kampung). The main dimensions and elements' sense of place were used as questionnaires' variables in the tourism kampung context. The result of this research explains sense of place model in the context of tourism kampong that consist of form, activity, and meaning which has sub variable namely place attachment and bonding.
\end{abstract}

Keywords: Sense of Place, Sense of Place Measurement, Tourism Kampung Development

\section{INTRODUCTION}

\section{The Development of Tourism Kampung}

City or urban area has a role as an activity centre that serves the needs of society surround it. Rapid urbanization that leads to population increasement in the city requires a good management and various facilities to support the development in accordance to seize potentials and thematic function of each city region (Febrianti, 2006). One vital function of urban areas is housing and human settlements. In the 
context of developing countries such as Indonesia, housing issues become one serious problem along with rapid population increasement due to urbanization. The increase of urban population leads to urban poverty and most of urban population have low education and skills and live in slum, crowded and unhealthy settlements inside the city (Rahardjo, 2014).

Kampung is a settlement that has rich potential value including the cultural conservation. The form of tangible culture can be seen through cultural relics of heritage housing. In the other hand, the intangible culture is represented by folk traditions in the community that is maintained and preserved. In line with Funo's assertion states that informal kampung in Indonesia are unique and distinctive (Funo et al 2002). The inhabitant's identity from different socio-cultural backgrounds shapes the kampung growth that has a heterogeneous and multi-dimensional community, ranging from social, cultural, and economic diversity. The city's government perceives these aspects as a potential value to develop tourism attractions in Kampung.

Tourism kampungs in Surabaya continue to improve their tourism components such as facilities, accessibility, and attraction for visitors to experience the community-based travel experience in the kampung. The visitors are targeted not only domestic tourists, but also foreign tourists who are interested to feel the ambience of kampung's life.

As result, the kampung has dualistic functions, which it remains as a settlement for their residents as well as being a community-based tourism destination as their commercial function. In this case, not only the physical aspects will be affected, but also non-physical dimensions such as socio-cultural aspects are change. This change is predicted to affect the perception of sense of place of the people who live in the kampung, before and after the development of the tourism kampung. Sense of place itself has a direct influence on the level of community participation in a development of place (Canter, 1977). When the sense of place is lost in a development of kampung, then the sustainability of the kampung will be threatened.

Sense of place is a concept that transforms space into a place with behaviour and social characteristics for a particular society (Relph, 1976). Sense of place generally studies human relationships with the environment; this is related to the emergence of awareness about the importance of cultural influences on the built environment itself. Individuals and collective values influence the sense of place. Sense of place is also influenced by human, social, and cultural behaviour (Canter, 1977). It is stated that the community's satisfaction, identification, and relationship of attachment to the community causing different levels of sense of place in different types of society (Hummon,1992).

David Canter's theory of place is developed to measure sense of place. The concept of sense of place has much to do with the concept of place, where this concept is one of the theoretical frameworks that capable in explaining the components of sense of place (Canter, 1977). According to Canter, a place consists of three dimensions which are form, imaginations, and activities. The efficiency of the Canter's model of place has led many other scientists from the urban design 
discipline to present various sub-models, one of them is the sense of place model from Phunter (1991). He defines the sense of place aspect of three components subversion of Canter model (1977) i.e. (1) form; (2) meaning; and (3) activity. These three aspects will then be used to analyse the influence of tourism kampung development on the sense of place of its community. The physical aspect of the form of sense of place is related to the spatial configuration and the condition of residential housing, the activity aspect is related to the pattern of community activity, whereas the aspect of meaning is related to the perception of the community towards the changing of physical and non-physical condition of the kampung as the impact of the development of the tourism kampung. These changes are predicted to affect the sense of place of the community, which is also be closely linked to the sustainability of community-based tourism kampung development.

This paper discusses the sense of place model in the context of tourism kampung's development based on some literature study (Canter (1977), Panter (1991), Montgomerry (1988), Ujang (2010)). Besides literature study, observation and in-depth interview in tourism kampung in Surabaya (Kampung Maspati) is also conducted to adjust theories in specific context of kampung. This argument is valuable to measure the sense of place of kampung as tourism attraction. The finding is also important to sustain development of kampung supported by high levels of community participation.

\section{THEORY/ METHODS}

\section{Definition of Place}

Discussing the definition of place is required before the sense of place concept is formed in the specific context. Place is a certain space that has been influenced by the meaning and value of its users. According to Tuan (1977), place is the centre of meaning constructed by experience. Tuan adds that space is physically a place when individuals are bound meaningfully with a geographical location. Each geographical location has a character and spirit of place associated with its nature. Place is a space that has a characteristic and a certain meaning for the environment (formed by individuals, groups, and cultural processes). Besides, the place has a meaning that can be reviewed from the point of contextuality, image and aesthetic value. Places are units of a space that have specific meanings, rules of conduct, and physical form (Tuan, 1977). In addition, place is generally a space that has meaning in terms of culture, individuality, and the process of social attachment, feeling, and emotion (Stedman, 2003).

Place has an important role in human life. Each place has its own unique character that is also an important issue in social science (Gustafson, 2001). In the world of architecture itself, the relationship between human behaviour and place has been widely discussed after the $80 \mathrm{~s}$, that many emerging psychological and behavioural factors influence the built environment, such as personal space, territory, space function, the meaning of space, and sense of place itself (Altman \& Low, 1992). 
Humans can create strong emotional bonds with a place. Human attachment to a place grows with the length of time when humans are living and doing activities in that place. However, the establishment of a place is a process derived from social interaction and activity within it. Place has an effective role in promoting social ties in urban communities (Loomrs \& Singer, 1980). In this case, Altman and Low mention that place is a means for cultural, social and individual relationships (Altman \& Low, 1992).

In place concept theory, a place can be presented or created through the process of identification and classification. Several researchers have defined the aspects of place-formers. For example, Gieryn (2000) explains place have three aspects and characters, namely (1) geographic location; (2) physical parameters; (3) an identity consisting of meaning and value. Meanwhile, the place according to Canter (1977), is the result of the relationship between (2) form (object and physical character); activities (human activities that occur therein); (3) imagination (meaning place to user / user). For more details, place theory from Canter (1977) can be seen in the following diagram (Figure 1).

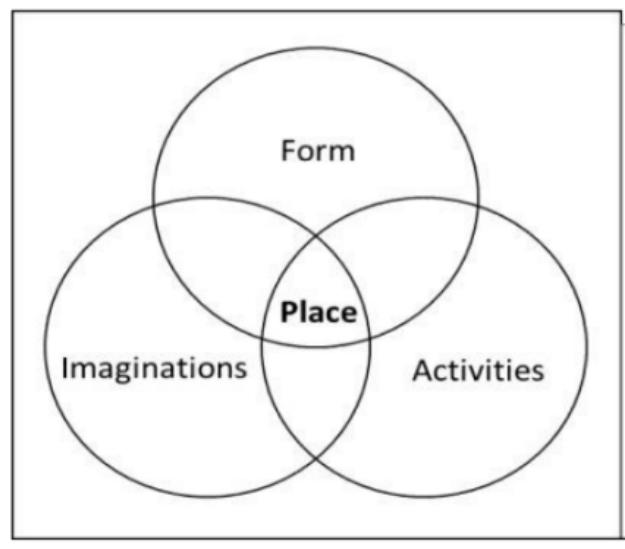

Figure1. Place Model

Source: Canter, 1997

This paper uses the Canter's place model as the main theory which is developed further, especially for the context of sense of place in tourism kampung development.

\section{Sense of Place}

Place has many supporting concepts, one of which is sense of place. Sense of place is a concept that transforms a typical space into a place with special behaviour and sensory characteristics for certain people. This means that human beings connect themselves to the place by understanding the daily activities and symbols associated with it. Sense of place forms and develops when humans live or are in a certain environment (Relph, 1976). Individuals and collective values can influence the sense of place, whereas the sense of place is also influenced by human, social, and cultural 
behaviour. Sense of place not only creates a harmonious relationship between humans and the built environment, but also creates a sense of security, happiness, and emotional awareness for the individual. Sense of place also creates identity of community and influences the level of community participation in its development (Canter, 1977).

Sense of place is a relationship rooted in the subjective experience of society (memory, tradition, history, and values in society) and on the other hand, it is also influenced by objective experiences and external influences (landscape) that leads to association to place. The sense of place is a fairly complex concept that connects human feelings and attachment to an environment that can be generated through the process of adaptation and the use of the environment by humans (Falahat, 2006).

\section{Sense of Place Variables}

The concept of sense of place has much to do with the concept of place that has been proposed by David Canter (1977). This concept is one of the theoretical frameworks to explain the components of sense of place. According to Canter, a place consists of three dimensions of form, imaginations, and activities. The appeal and efficiency of the component model place of Canter has led many other scientists from the urban design discipline to present various sub-models. For instance, Phunter (1991) defines the model of sense of place aspect into three components which is subversion from Canter's model (1977) i.e. (1) form; (2) meaning; and (3) activity (Figure 2).
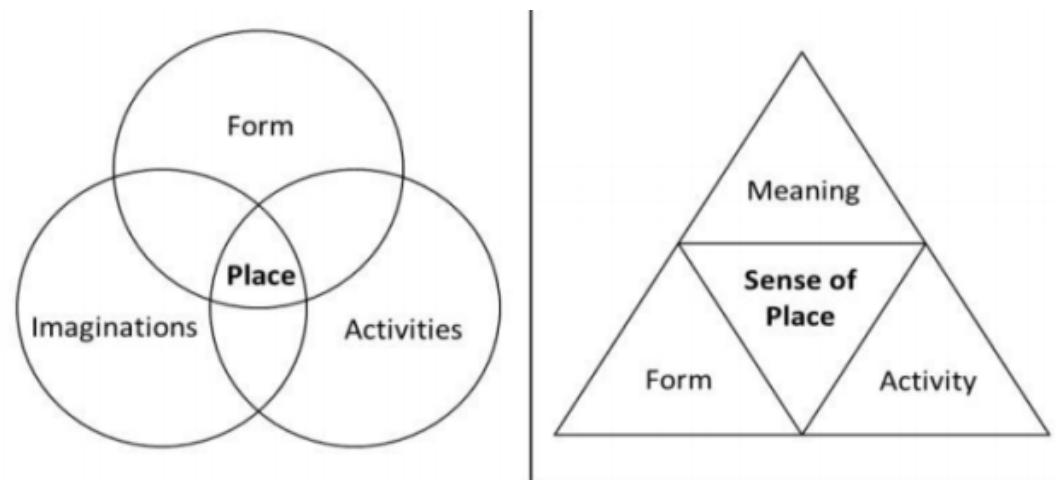

Figure 2. Sense of Place Model

Source: Canter, 1997; Phunter, 1991 in Ghoomi et al, 2015

Phunter concept includes three related aspects of the form (physical), meaning (meaning), and activity (activity). These three aspects are further elaborated into several aspects (Phunter 1991 in Montgomery, 1998) (Figure 3). 


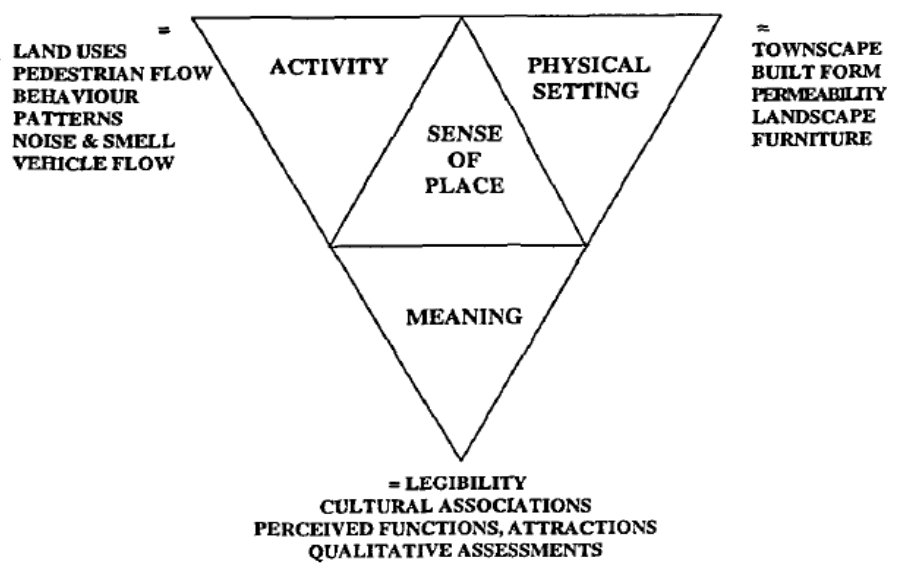

Figure 3. Sense of Place Model by Phunter Source: Phunter, 1991 in Montgomery, 1998

Furthermore, Montgomery (1998) in his writings Making a city: urbanity, vitality and urban design reveals that there are several aspects of direction to strengthen a sense of place (Figure 4).

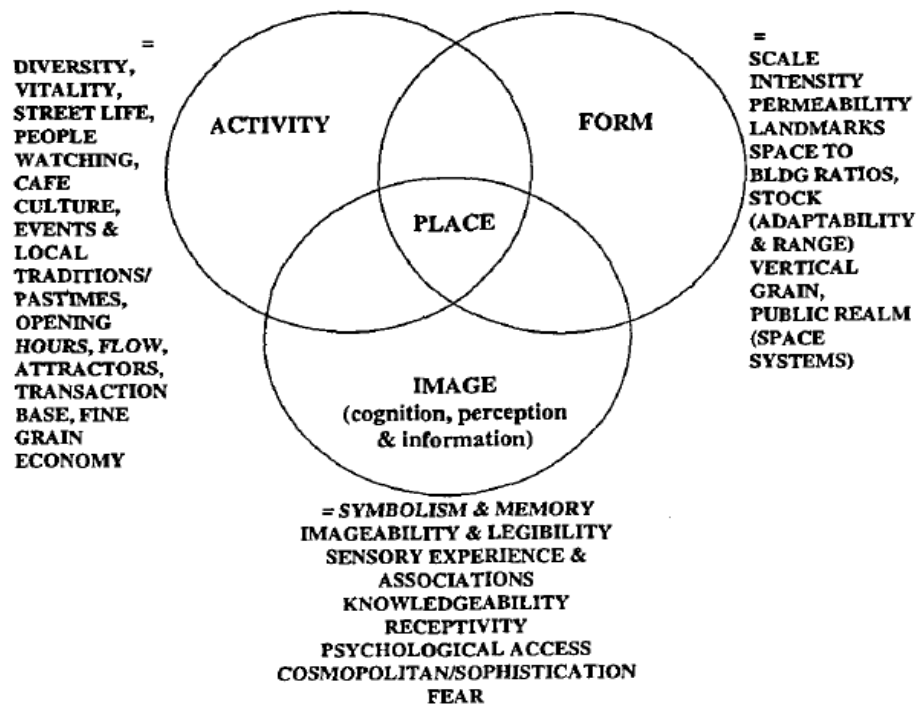

Figure 4. Sense of Place Model by Montgomery

Source: Montgomery, 1998

In its development, the sense of place model from Canter (1977), Phunter (1991), and Montgomery (1998) are used and developed by many modern researchers in certain contexts. For example, Ujang (2010) applies the model to 
examine the sense of place in shopping streets in Kuala Lumpur, Malaysia. In this context, Ujang has applied the following aspects (Table 1).

Table 1. Sense of Place Model

\begin{tabular}{lll}
\hline Place & Aspects & Variables \\
\hline Form & Accessibility & Location, Access, Layout \\
& Legibility & Signage, Greenery/trees, View, \\
& & Landscape features, \\
& & Building and facade, \\
Activities & Landmark/Nodes. \\
& Vitality & Shopping complexes \\
& Diversity/ & Street activity \\
& Choice & People watching, Entertainment \\
& & Products/services \\
& & Food and eating spots \\
& Day and night activities \\
& Transaction & Mixture of people \\
& Price \\
& Legibility & Banking and communication centres \\
Distinctiveness & Street vendors \\
& Image and Popularity \\
& Comfort & Public open spaces, Distinction, \\
& Uniqueness, Traditional \\
& Resting space, Convenience, \\
& Facilities, Environmental quality, \\
& & Maintenance \\
& Surveillance \\
& Pedestrian \\
\hline &
\end{tabular}

Meanwhile in the context of kampung in Indonesia, there are several unique physical features that are different from other contexts. Some features have been identified by Hutama, 2014 (Table 2).

Table 2. Physical Features of Kampung

\begin{tabular}{lll}
\hline $\begin{array}{l}\text { Social Space } \\
\text { in Kampung }\end{array}$ & Characters & Description \\
\hline $\begin{array}{l}\text { Pathways/ } \\
\text { Kampung } \\
\text { Alley }\end{array}$ & $\begin{array}{l}\text { Organic and } \\
\text { dynamic, roads } \\
\text { ranging from wide } \\
\text { to narrow }\end{array}$ & $\begin{array}{l}\text { In general, the alley in the village is directly } \\
\text { connected to the terrace of the resident's } \\
\text { house. Where the private space is much } \\
\text { changed into semi-public space or even } \\
\text { public. This space is the space that most } \\
\text { accommodate community interaction. }\end{array}$ \\
$\begin{array}{l}\text { Kiosk/ Food } \\
\text { Stall }\end{array}$ & $\begin{array}{l}\text { Home Based } \\
\text { Enterprises, semi } \\
\text { permanent's }\end{array}$ & $\begin{array}{l}\text { In urban kampungs, kiosk or stalls not only } \\
\text { serve as providers of citizen needs, but also as } \\
\text { a gathering point for citizens to socialize. }\end{array}$ \\
\hline
\end{tabular}


Table 2. Physical Features of Kampung (continued)

\begin{tabular}{|c|c|c|}
\hline $\begin{array}{l}\text { Social Space } \\
\text { in Kampung }\end{array}$ & Characters & Description \\
\hline & construction & $\begin{array}{l}\text { This place can accommodate longer social } \\
\text { interactions and provides a symbol or identity to } \\
\text { the community. }\end{array}$ \\
\hline $\begin{array}{l}\text { Social } \\
\text { Facilities } \\
\text { (Communal } \\
\text { Space, Balai } \\
\text { Warga, Pos } \\
\text { Kamling, } \\
\text { Mosque, and } \\
\text { others) }\end{array}$ & $\begin{array}{l}\text { Public use, } \\
\text { symbolic } \\
\text { representation } \\
\text { of a } \\
\text { community }\end{array}$ & $\begin{array}{l}\text { Social facilities within the village certainly have a } \\
\text { significant role in accommodating the social } \\
\text { interaction of the community and become a social } \\
\text { system that binds the community (Setiawan, 2010). }\end{array}$ \\
\hline $\begin{array}{l}\text { Field and } \\
\text { Open Space }\end{array}$ & $\begin{array}{l}\text { The size is } \\
\text { limited, part of } \\
\text { the remaining } \\
\text { land }\end{array}$ & $\begin{array}{l}\text { The atmosphere of a field or open space in the } \\
\text { kampung can be diverse and used for diverse } \\
\text { activities such as celebrations/ events, social } \\
\text { interactions, cooking together, drying clothes, and } \\
\text { so on. }\end{array}$ \\
\hline
\end{tabular}

\section{Kampung as Tourism Attraction}

Kampung is a general urban settlement in Indonesia that has its own characteristics and uniqueness (Funo, 2002). Kampung is one form of Indonesia's settlement that is mostly occupied by low-income communities. However, kampung conditions in Indonesia cannot always be generalized as "slum" or "squatter". The kampung has unique characteristics, different developmental processes, and attachment to the environment and its respective communities (Herbasuki, 1984). Residents who live in kampung bring their local identity from village to the kampung. Therefore, kampung has been growth as residential area that has a multi-dimensional community, ranging from social, cultural, and economic diversity. That is emphasized where the kampung has a heterogeneous community and a complex population that usually still holds traditional values (Funo, 2002). Kampung has a diverse community that still preserved their traditional values. The value of traditional culture is seen by the municipal government as a potential aspect that can be developed into tourism attractions.

As a tourism attraction, kampung have to escalate their facilities to meet tourism standard. Kampung have to add several things related to tourism component (Inskeep (1991); Antara (2011)), such as:

1. Attractions, consist of site attractions (either nature or man-made) and event attractions (such as culture, sports, or any activity involving the tourists).

2. Amenities, include many accommodation facilities, such as service and reception (restaurants, shops, crafts and souvenirs, information office), finance (banks, money changers), personal (salon), health, public security 
(police station, firefighters), travel (immigration, customs), or transportation. This part also includes basic infrastructure.

3. Accessibilities, in the form of access to tourism destination that is affordable, practical, and easy.

4. Tourist organization, formation of organization which composes and manages all about tourism activities, including advertises tourism attractions

\section{RESULTS AND DISCUSSION}

\section{Sense of Place in Tourism Kampung}

Sense of place itself is formed and developed when humans live in a certain environment (Relph, 1976). Individuals and collective values also influence the sense of place, whereas sense of place can also be influenced by human, social, and cultural behaviour. Sense of place also affects the level of community participation in a development (Canter, 1977). Subsequently, if the sense of place of a society is disturbed, it will cause a direct impact on the sustainability of development, including the sustainability of tourism village development.

In this section, the aspects of the measurement of the sense of place is summarized in the context of the development of a tourism kampung in Surabaya that refers to the previous literature review which is the subversion of the theory of sense of place from David Canter (1977) and Phunter (1991). Aspects of form, activity, and meaning are adapted to the context of the tourism kampung Development in the city of Surabaya (Figure 5).
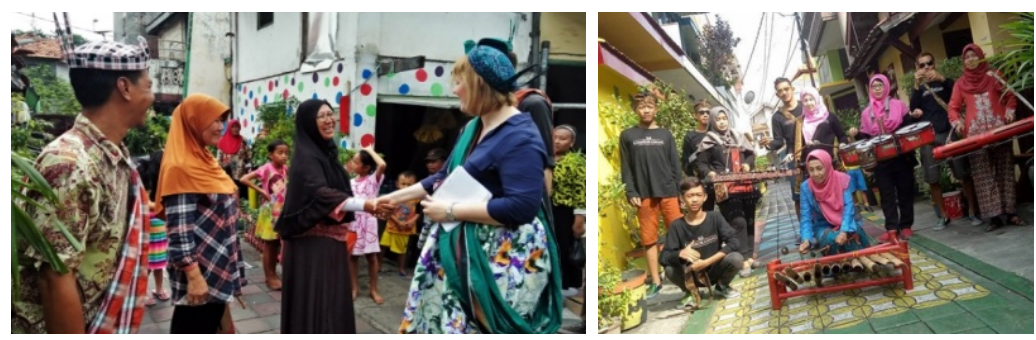

Figure 5. Tourism Kampung in Indonesia (Kampung Maspati, Surabaya) Source: Writer, 2018

Next, the discussion starts to explain the Canter's theory (1977) of sense of place aspects and then these will be elaborated with field observations and in-depth interviews in the context of tourism kampung in Surabaya.

\section{Form Aspects of Sense of Place}

This physical aspect (form) has a significant role in influencing the sense of place. Physical aspects contribute to making a place easier for users to read, where the environment can be identified, organized and directed by society (Lynch, 1960). 
In a built environment, according to Lynch (1997), sense of place is a factor that creates a link or relationship between man and the environment (place). Sense of place makes the relationship between the two into a unite unity. A space must also have a clear identity and must be identifiable, memorable, and clear (obvious) to create a sense of place (Lynch, 1997).

From literature study and some field observatory, it can be summarized that form/ physical variable of sense of place in tourism kampung are mentioned as follows (Table 3).

Table 3. Form Variable of Sense of Place

\begin{tabular}{|c|c|c|c|c|}
\hline Variable & Sub-Variable & $\begin{array}{l}\text { Operational } \\
\text { Definition }\end{array}$ & Indicator & Source \\
\hline \multirow[t]{4}{*}{ Form } & $\begin{array}{l}\text { Kampung } \\
\text { Layout }\end{array}$ & $\begin{array}{l}\text { Configuration of } \\
\text { space in the village } \\
\text { layout to identify } \\
\text { the socio-spatial } \\
\text { environment }\end{array}$ & $\begin{array}{ll}\text { - } & \text { Connectivity } \\
\text { - } & \text { Integration } \\
\text { - } & \text { Intelligibility }\end{array}$ & $\begin{array}{l}\text { Phuter (1991); Bill } \\
\text { Hilier (1984) }\end{array}$ \\
\hline & $\begin{array}{l}\text { Building Form } \\
\text { and Facade }\end{array}$ & $\begin{array}{l}\text { The shape and } \\
\text { facade of buildings } \\
\text { associated with the } \\
\text { architectural style } \\
\text { and conditions of } \\
\text { the village }\end{array}$ & $\begin{array}{ll}\text { - } & \text { Architecture } \\
\text { Style } \\
\text { - } & \text { Building } \\
\text { Condition }\end{array}$ & $\begin{array}{l}\text { Phunter (1991); } \\
\text { Ujang (2010) }\end{array}$ \\
\hline & $\begin{array}{l}\text { Street } \\
\text { Furniture }\end{array}$ & $\begin{array}{l}\text { Components in the } \\
\text { road and alley } \\
\text { areas are linked to } \\
\text { the function of the } \\
\text { road as the main } \\
\text { public space in the } \\
\text { village }\end{array}$ & $\begin{array}{ll}\text { - } & \text { Sidewalks } \\
\text { Components } \\
\text { - } & \text { Road Utility } \\
\text { Components } \\
\text { - } \quad \text { Gang / Road } \\
\text { Components }\end{array}$ & $\begin{array}{l}\text { Phunter (1991); } \\
\text { Ujang (2010) }\end{array}$ \\
\hline & Landmark & $\begin{array}{l}\text { A landmark that } \\
\text { can serve as the } \\
\text { point that becomes } \\
\text { the identity of an } \\
\text { area }\end{array}$ & $\begin{array}{ll}\text { - } & \text { Local Citizen } \\
\text { Landmark } \\
\text { - } & \text { Tour } \\
\text { Landmarks }\end{array}$ & $\begin{array}{l}\text { Montgomery } \\
\text { (1998); } \\
\text { Lynch (1975) }\end{array}$ \\
\hline
\end{tabular}

Source: Writer, 2018

\section{Activity Aspects of Sense of Place}

Within its function to accommodate the activities of its users, a place is required to be responsive, functional, and vital. Vitality is defined as the ability or activity of a place to accommodate activities because of the intensity and diversity of activities produced by its users (Jacobs, 1961, Montgomery, 1998). In this case, Shuhana (2004) finds that activities also affect people's perceptions. A good place is an environment that has a variety of physical (form), economy, and social diversity. A good place also has a relatively long activity period that can contribute to a vital and secure public space (Jacobs, 1999). 
In this case, the function and meaning of kampung which is only as a settlement system has turned into a tourism destination that have to open their kampung more accessible to the public (tourists). The kampung may allow the visitors to feel and experience the place within the kampung. This leads the kampung to have a dual function, which remains as a settlement for its inhabitants as well as being a community-based tourist destination as a commercial function. In this case, changes are taken place in the pattern of community activities, both domestic activities and social activities between citizens and tourists. The activity variable of sense of place is explained below (Table 4).

Table 4. Activity Variable of Sense of Place

\begin{tabular}{|c|c|c|c|}
\hline $\begin{array}{l}\text { Sub } \\
\text { Variable }\end{array}$ & Operational Definition & Indicator & Source \\
\hline Activity & $\begin{array}{l}\text { Activities that occur in the } \\
\text { village tourism, associated } \\
\text { with villagers and tourists }\end{array}$ & $\begin{array}{ll}\text { - } & \text { Necessary } \\
& \text { Activity } \\
\text { - } & \text { Optional } \\
& \text { Activity } \\
\text { - } & \text { Social } \\
\text { Activity } \\
\text { (Internal) } \\
\text { - } & \text { Social } \\
\text { Activity } \\
\text { (Tourism) }\end{array}$ & $\begin{array}{l}\text { Phunter (1991); } \\
\text { Montgomery (1998); } \\
\text { Ujang (2010); Gehl } \\
(2013)\end{array}$ \\
\hline $\begin{array}{l}\text { Behaviour } \\
\text { Setting } \\
\text { Patterns }\end{array}$ & $\begin{array}{l}\text { The addition of variable } \\
\text { milieu (setting and time) on } \\
\text { the activity so that it can see } \\
\text { the tendency of user } \\
\text { behaviour patterns in the } \\
\text { tourist village }\end{array}$ & $\begin{array}{l}\text { - Weekdays and } \\
\text { Weekend }\end{array}$ & $\begin{array}{l}\text { Phunter (1991); } \\
\text { Gehl (2013) }\end{array}$ \\
\hline Flow & $\begin{array}{l}\text { Components in the road and } \\
\text { alley areas are linked to the } \\
\text { function of the road as the } \\
\text { main public space in the } \\
\text { village }\end{array}$ & $\begin{array}{l}\text { - See the flow } \\
\text { and sequence } \\
\text { trends in } \\
\text { tourism } \\
\text { activities }\end{array}$ & $\begin{array}{l}\text { Montgomery } \\
\text { (1998); Gehl } \\
(2013)\end{array}$ \\
\hline $\begin{array}{l}\text { Social } \\
\text { Interaction }\end{array}$ & $\begin{array}{l}\text { A landmark that can serve as } \\
\text { the point that becomes the } \\
\text { identity of an area }\end{array}$ & $\begin{array}{ll}\text { - } & \text { Actor } \\
\text { - } & \text { Form } \\
\text { - } & \text { Intensity }\end{array}$ & $\begin{array}{l}\text { Ujang (2010); } \\
\text { Vali (2014) }\end{array}$ \\
\hline
\end{tabular}

Source: Writer, 2018

\section{Meaning Aspects of Sense of Place}

In the tourism kampung context, there is a significant change in the meaning of kampung as an informal housing from a community's settlement system into a tourism kampung. This change makes kampung having dual function which are settlement and tourism function. Tourism kampung remains as housing area for its residents, but the access will be open for public and tourist as its function as tourism 
attraction. Along with this case, tourism kampung development is predicted to affect resident's perception level of sense of place

Therefore, it is important to measure the meaning perception changing of the community. The meaning aspects of sense of place is quite abstract, so it needs to be combined with other supporting theories. Place attachment is one of theories that is used to measure meaning aspects of sense of place.

In Place Attachment, there are three important aspects that influence and simultaneously as a means of measuring the level of place attachment of a person, namely place identity and place dependence, social bonding, and nature bonding (Raymond, 2010) (Figure 6).

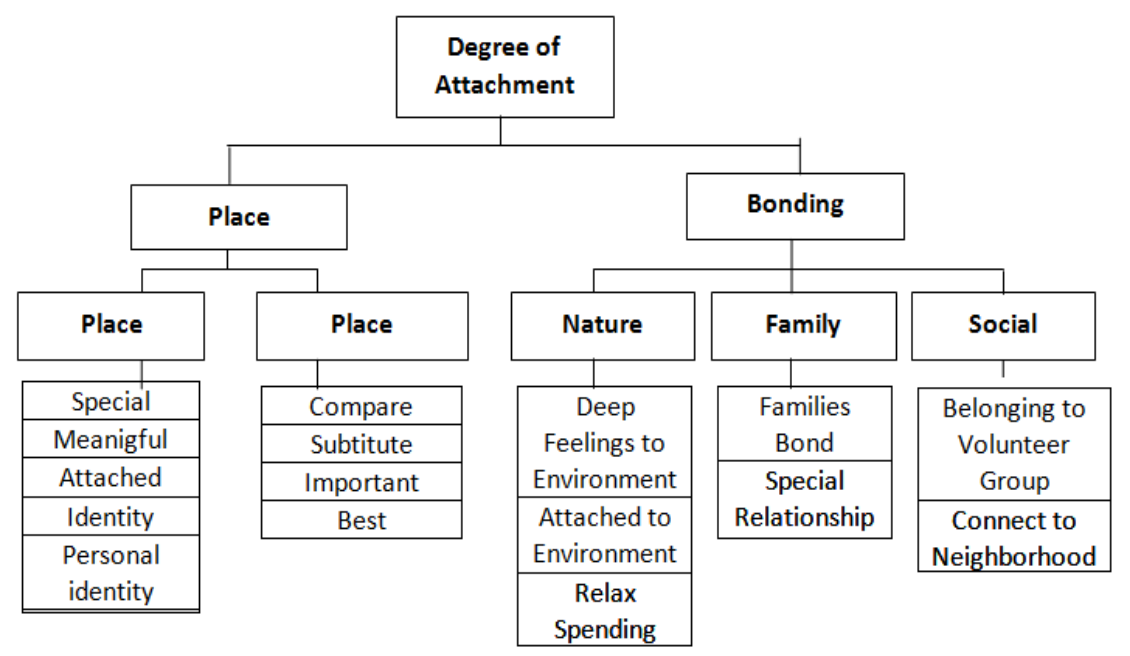

Figure 6. Place Attachment Model Source: Raymond, 2010

In line with Raymond's (2010), place attachment according to Ujang (2010) proposes two aspects, namely emotional attachment and functional attachment. The operational definition of emotional attachment is the same as place identity that is the dimension of personal, such as the combination of emotion to specific physical setting and symbolic connection to a place. Whereas, functional attachment is the same as place dependence that is specific function-based connection to individual physical connection to a setting; for example, the comfort level of inhabitants to stay in one place. Aspects of place attachment aspect according to Ujang are as follows (Figure 7). 


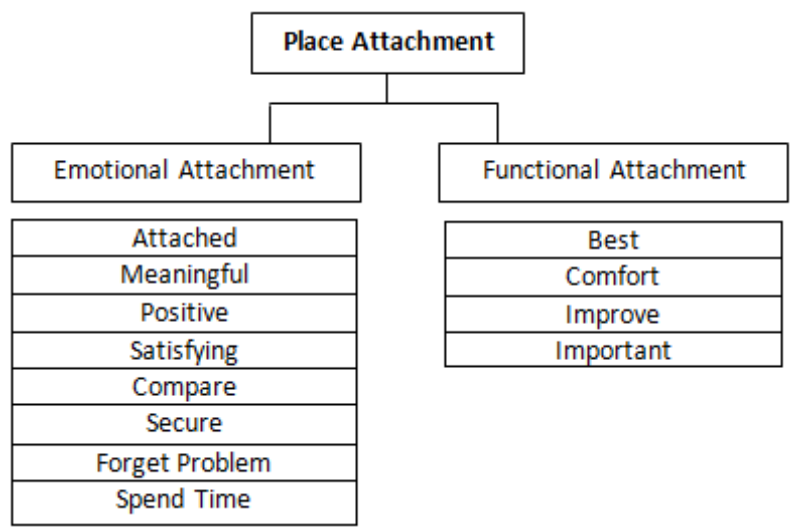

Figure 7. Place Attachment Model Source: Ujang (2010)

From these two literature studies, the synthesis of literature review proposes variables to measure aspect of meaning sense of place as follows (Figure 8).

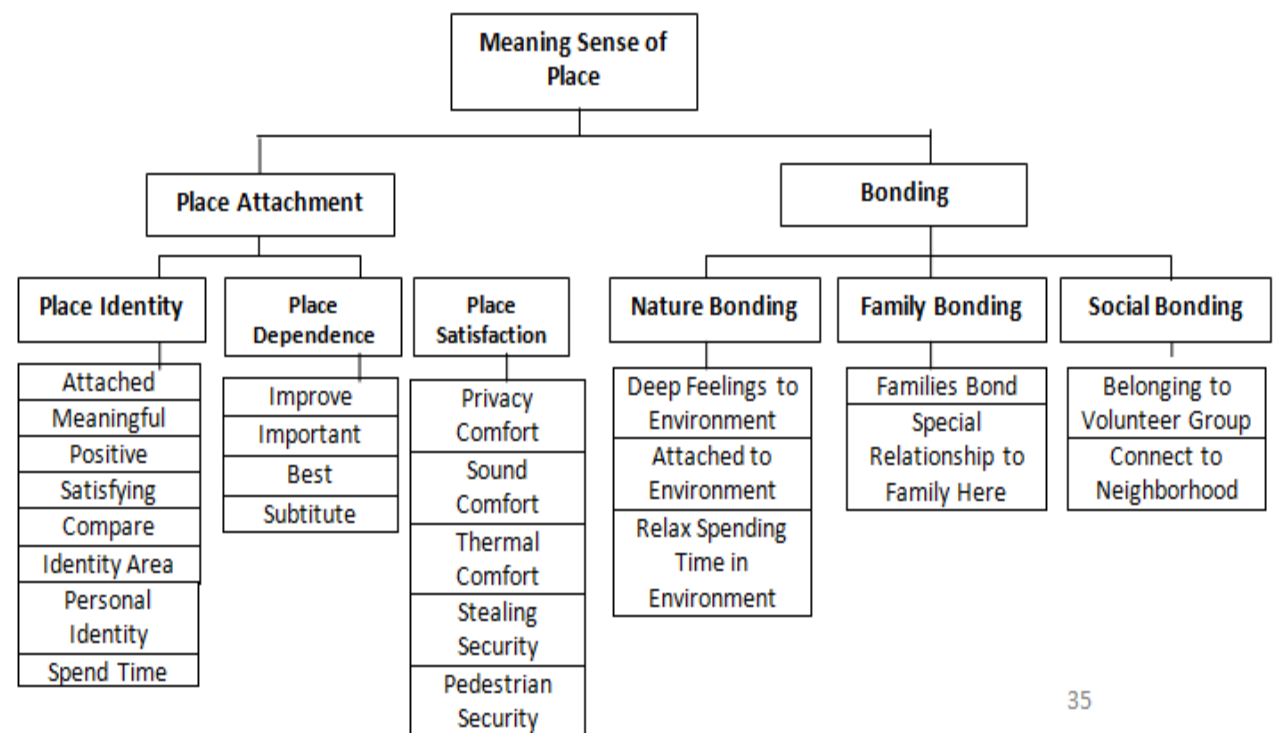

Figure 8. Meaning of Sense of Place Model

Source: Writer (2018)

From previous model, the meaning variables used to measure sense of place level in the context of tourism kampung are as follows (Table 5): 
Table 5. Meaning Variable of Sense of Place

\begin{tabular}{|c|c|c|c|c|}
\hline Variable & Sub Variable & $\begin{array}{l}\text { Operational } \\
\text { Definition }\end{array}$ & Indicator & Source \\
\hline \multirow[t]{5}{*}{ Meaning } & $\begin{array}{l}\text { Place } \\
\text { Identity }\end{array}$ & $\begin{array}{l}\text { Dimensions of the } \\
\text { personality, such as } \\
\text { the combination of } \\
\text { emotions to specific } \\
\text { physical settings } \\
\text { and symbolic } \\
\text { connections to a } \\
\text { place }\end{array}$ & $\begin{array}{l}\text { - Attached } \\
\text { - Meaningful } \\
\text { - Positive/special } \\
\text { - Satisfying } \\
\text { - Compare } \\
\text { - Identity area } \\
\text { - Personal identity } \\
\text { - Spend time }\end{array}$ & $\begin{array}{l}\text { Prohansky } \\
\text { et al. 1983; } \\
\text { William et } \\
\text { al 1992; } \\
\text { William \& } \\
\text { Vaske } 2003\end{array}$ \\
\hline & $\begin{array}{l}\text { Place } \\
\text { Dependence }\end{array}$ & $\begin{array}{l}\text { Specific functional } \\
\text { connections to } \\
\text { individual physical } \\
\text { connections to a } \\
\text { setting; for } \\
\text { example, describes } \\
\text { the degree to which } \\
\text { physical settings } \\
\text { can support user } \\
\text { activity }\end{array}$ & $\begin{array}{l}\text { - Improve } \\
\text { - Important } \\
\text { - Best } \\
\text { - Substitute }\end{array}$ & $\begin{array}{l}\text { Schreyer et } \\
\text { all, 1981; } \\
\text { William et } \\
\text { al, 1992; } \\
\text { William \& } \\
\text { Vaske, 2003 }\end{array}$ \\
\hline & $\begin{array}{l}\text { Place } \\
\text { Satisfaction }\end{array}$ & $\begin{array}{l}\text { Convenience and } \\
\text { security of the } \\
\text { community towards } \\
\text { the change of } \\
\text { village as a tourist } \\
\text { village }\end{array}$ & $\begin{array}{l}\text { - Privacy comfort } \\
\text { - Sound comfort } \\
\text { - Thermal comfort } \\
\text { - Stealing security } \\
\text { - Pedestrian } \\
\text { security }\end{array}$ & $\begin{array}{l}\text { Ujang } \\
(2010)\end{array}$ \\
\hline & $\begin{array}{l}\text { Social } \\
\text { Bonding }\end{array}$ & $\begin{array}{l}\text { Feelings of } \\
\text { belonging or } \\
\text { belonging in a } \\
\text { group, such as } \\
\text { neighbours and } \\
\text { family, such as } \\
\text { shared historical } \\
\text { emotional } \\
\text { connections, } \\
\text { interests, and } \\
\text { common goals }\end{array}$ & $\begin{array}{l}\text { - Family is here } \\
\text { - Special } \\
\text { relationship to } \\
\text { family here } \\
\text { - Belonging to } \\
\text { volunteer group } \\
\text { - Connect to } \\
\text { neighbourhood }\end{array}$ & $\begin{array}{l}\text { Kasardra \& } \\
\text { Janoi }\end{array}$ \\
\hline & $\begin{array}{l}\text { Nature } \\
\text { Bonding }\end{array}$ & $\begin{array}{l}\text { Implicit and explicit } \\
\text { connections to } \\
\text { some parts of the } \\
\text { environment, based } \\
\text { on history, } \\
\text { emotional response } \\
\text { or cognitive } \\
\text { representation }\end{array}$ & $\begin{array}{l}\text { - Deep feeling to } \\
\text { nature } \\
\text { - Attached to } \\
\text { environment } \\
\text { - Relax spending } \\
\text { time in } \\
\text { environment }\end{array}$ & $\begin{array}{l}\text { Kals et al, } \\
\text { 1999; } \\
\text { Clayton, } \\
\text { 2003; } \\
\text { Schultz; } \\
\text { 2001; Scutz, } \\
2004\end{array}$ \\
\hline
\end{tabular}


From that variable can be drawn some core questions related to the sense of place in order to examine the changing level of sense of place changes in the meaning aspects in smaller context (tourism kampung development) (Table 6).

Table 6. Meaning Variable Question of Sense of Place

\begin{tabular}{l}
\hline Place Identity \\
\hline I really feel at home in this village (Attached) \\
This village is very meaningful to me (Meaningful) \\
Kampung maspati is a famous village in Surabaya (Positive) \\
Staying in this village is very fun for me (Satisfying) \\
I feel at home in this village (Compare) \\
This village has a unique character compared to other villages (Identity Area) \\
Living in the village of old maspati is a proud thing for me (personal identity) \\
I want to spend my old age in this village (Spend Time) \\
\hline Place Dependence \\
\hline I am happy and agree with the development in this village (Improve) \\
This village is very meaningful to me (Important) \\
This village is the best place to live than anywhere else (Best, Substitute)
\end{tabular}
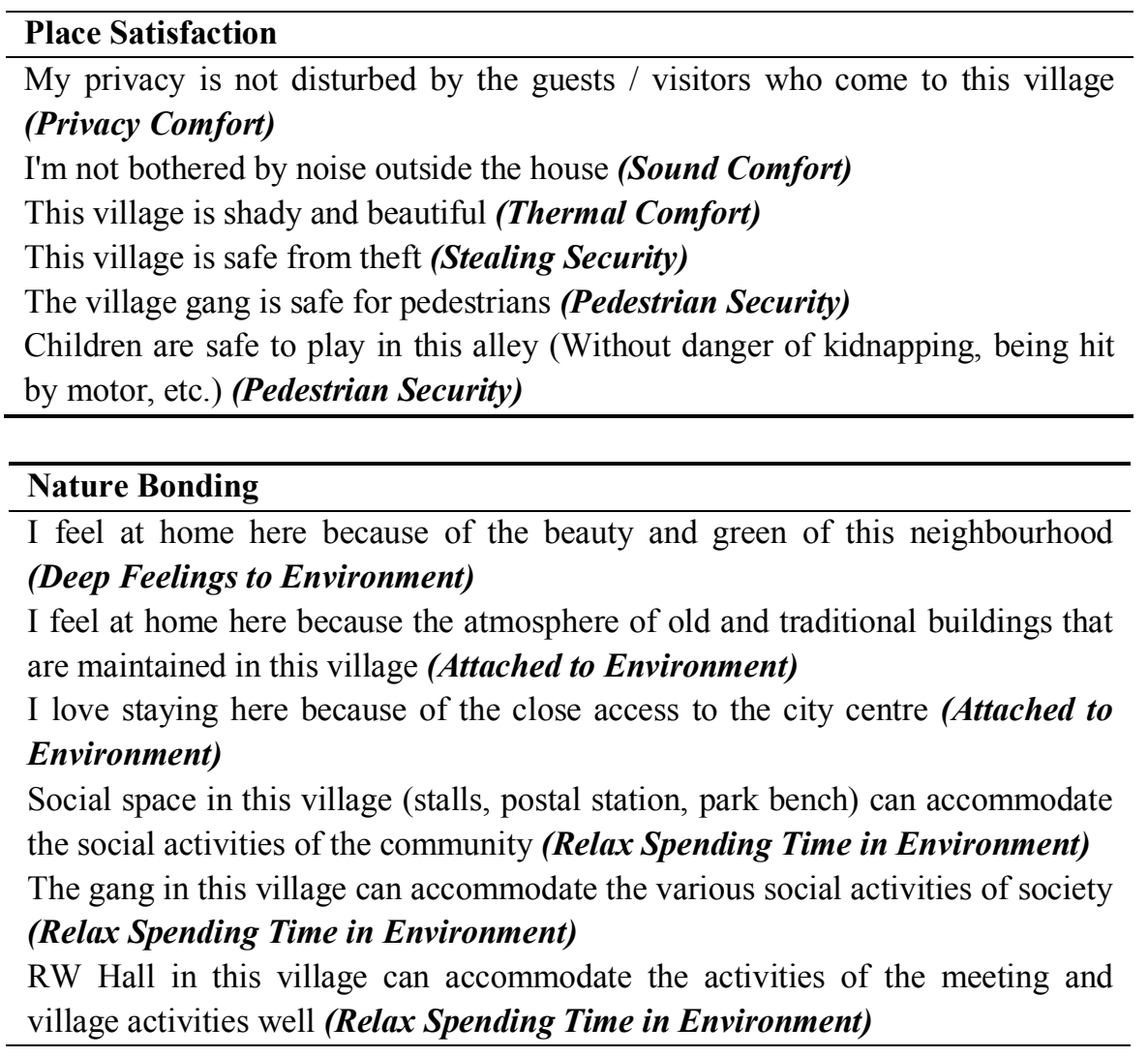
Table 6. Meaning Variable Question of Sense of Place (Continued)

\begin{tabular}{l}
\hline Family Bonding \\
\hline How many of your relatives live in this village? (Families Bond) \\
I live in this village because many of my family and relatives live here (Special \\
Relationship to Family Here)
\end{tabular}

\begin{tabular}{l}
\hline Social Bonding \\
\hline My neighbour at this friendly village (Connect to Neighbourhood) \\
I live in this village because the neighbourhood is very pleasant (Connect to \\
Neighbourhood) \\
Social activities in this village is very diverse (Connect to Neighbourhood) \\
I am always actively involved in the activities of this old village (volunteers, \\
meetings, arisan, pkk, tour meetings) (Belonging to Volunteer Group) \\
\hline
\end{tabular}

\section{CONCLUSION}

From the discussion above, the aspects of sense of place schematic model have been identified and can be used as research's variables in the tourism kampung context. (Figure 9). With this model, the level of each variables (form, activity, and meaning) of community's sense of place can be measured.

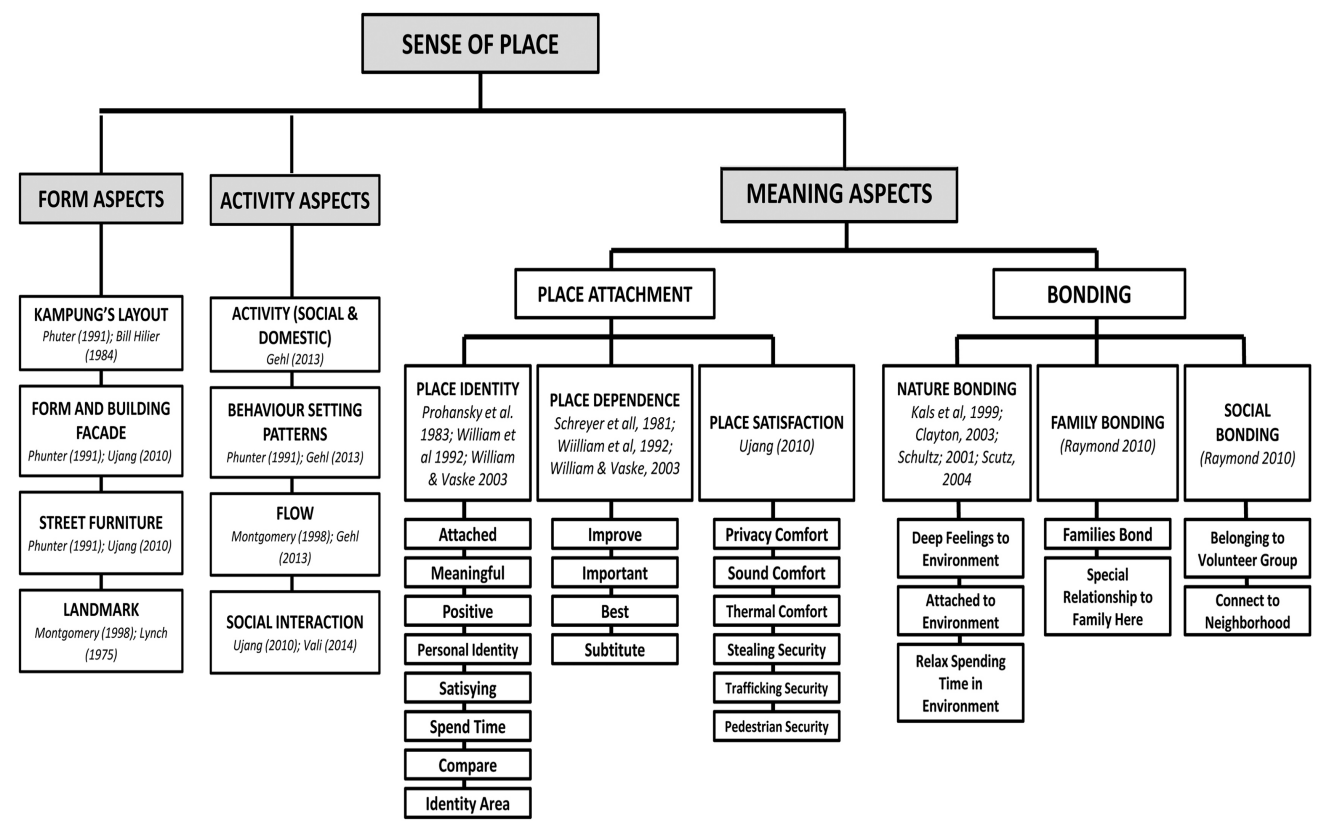

Figure 9. Schematic Model of Sense of Place in Tourism Kampung Development Source: Writer, 2018 
The model of this study can be tested in the context of tourism kampung development and valuable to enrich its theoretical framework. The analysis used in the model is by reviewing different theories of sense of place that shows shared definition of what constitutes a sense of place, its features, and its performance in the specific context (tourism kampung). The development theory of sense of place in specific context, such as tourism kampung, can support the direction for trilogy sustainable development concept in tourism kampungs. Furthermore, the identified variables can be used to form a questionnaire for other research of sense of place in the tourism kampung context.

\section{REFERENCES}

Antara. (2011). Strategi pengembangan pariwisata alternatif di Desa Pelaga Kecamatan Petang Kabupaten Badung”. Denpasar: Program Magister Program Studi Kajian Pariwisata, Universitas Udayana. 2011

Altman I \& Low S. (1992) Human behaviour and environments: Advances in theory and research. Volume 12: Place attachment. New York: Plenum Press.

Canter D (1977a) The Psychology of Place. London: Architectural Press. Canter D (1977b) Book review of E. Relph, 'Place and placelessness'. Environment and Planning B, 4, 118-120

Falahat, M. (2006) Sense of place and the factors shaping it. Fine Arts Magazine, 26.

Febrianti, A. W. (2006) Tingkat Pemenuhan Dan Aksesibilitas Fasilitas Sosial Di Kecamatan Semarang Selatan Dan Kecamatan Genuk. Perencanaan Wilayah Dan Kota, Universitas Diponegoro.

Funo, S. Yamamoto N. and Silas, J. (2002) Typology of Kampung Houses and Their Transformation Process, a Study on Urban Tissues of an Indonesian City. Journal of Asian Architecture and Building Engineering/JAABE vol.1 no.2, 193-200.

Gehl, Jan (2006). Life Between Buildings: Using Public Spaces. Copenhagen: Danish Architectural Press

Gehl, J. and Svarre, B. (2013) How to Study Public Life, Island Press

Gustafson P. (2001b) Meanings of place: Everyday experience and theoretical conceptualizations. Journal of Environmental Psychology 21, 5-16.

Hutama, Irsyad. (2016) Exploring the Sense of place of Urban Kampung. Netherland: Enschede.

Hummon DM (1992) Community Attachment: Local Sentiment \&Sense of place. New York: Plenum.

Inskeep. (1991) "Tourism Planning An Integrated and Sustainable Development Approach". New York: Van Nostrand Reinhold

Lynch, K. (1960) The Image of the City. Cambridge, Massachusetts: MIT Press

Montgomery. (1998) Making a city: Urbanity, vitality and urban design, Journal of Urban Design, 3:1, 93-116, DOI: 10.1080/13574809808724418 
Proshansky HM, Fabian AK, \& Kaminoff R. (1983) Place identity: Physical world socialization of the self. Journal of Environmental Psychology 3, 57-83

Punter, J. (1991) Participation in the design of urban space, Landscape Design, 200, pp. 24-27.

Relph E (1976) Place and Placelessness. London: Pion Limited.

Rahardjo et al, "Key Success Factors for Public Private Partnership in Urban Renewal in Jakarta" IACSIT International Journal of Engineering and Technology, Vol. 6, No. 3, June 2014 available at http://www.ijetch.org/papers/699-W10025.pdf

Stedman RC. (2003) Sense of place and forest science: toward a program of quantitative research. Forest Science 49(6): 1-8.

TuanYF (1977) Space and Place: The Perspective of Experience. London: Edward Arnold

Ujang, N., (2008) Place Attachment Towards Shopping District in Kuala Lumpur City Centre. Universiti Peutra Malaysia. Unpublished Theses Degree of Doctor of Philosophy

Vali, Amirhoosein Pouriyaye (2014). The concept and sense of place in architecture from phenomenological approach. Indian Journal of Fundamental and Applied Life Sciences

Yudohusodo, Siswono, dkk. (1991) Rumah untuk Seluruh Rakyat, INKOPPOL, Jakarta 